Document downloaded from:

http://hdl.handle.net/10251/58728

This paper must be cited as:

Femenia Ribera, C.; Benítez Aguado, E.; Mora Navarro, JG.; Martínez Llario, JC. (2014). Method of recovering municipal boundary lines in Province of Valencia (Spain) by means of historical cadastral maps. Survey Review. 46(337):255-266. doi:10.1179/1752270613Y.0000000081.

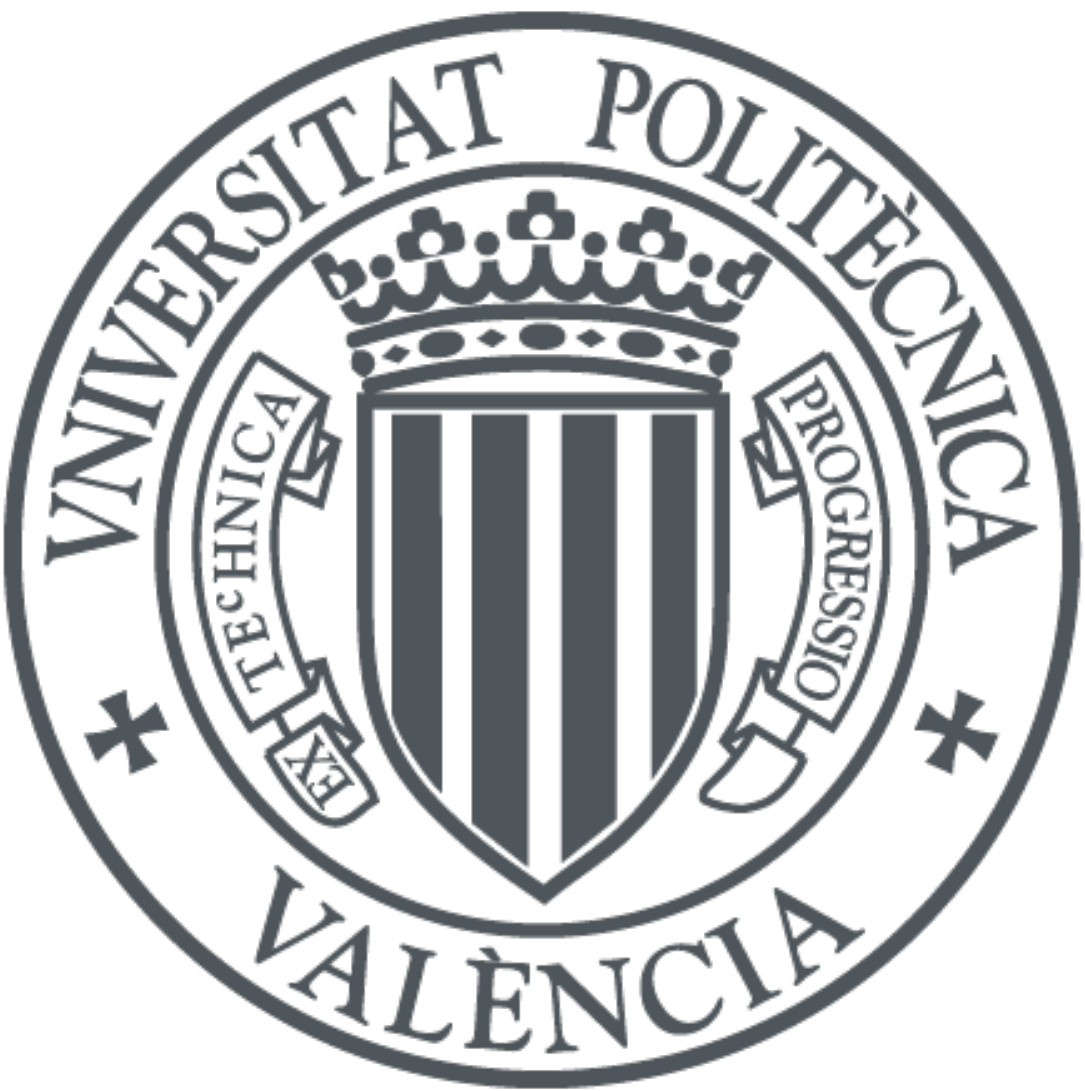

The final publication is available at

http://dx.doi.org/10.1179/1752270613Y.0000000081

Copyright Maney Publishing

Additional Information 


\title{
A METHOD OF RECOVERING MUNICIPAL BOUNDARY LINES IN THE PROVINCE OF VALENCIA (SPAIN) BY MEANS OF HISTORICAL CADASTRAL MAPS
}

\author{
Carmen Femenia-Ribera
}

Departamento de Ingeniería Cartográfica, Geodesia y Fotogrametría, Universitat

Politècnica de València, Spain

Emilio Benitez-Aguado

Departamento de Ingeniería Cartográfica, Geodesia y Fotogrametría, Universitat Politècnica de València, Spain

Gerencia Regional Catastro Valencia, Spain

\section{Gaspar Mora-Navarro}

Departamento de Ingeniería Cartográfica, Geodesia y Fotogrametría, Universitat Politècnica de València, Spain

\section{Jose Martinez-Llario}

Departamento de Ingeniería Cartográfica, Geodesia y Fotogrametría, Universitat Politècnica de València, Spain

\section{ABSTRACT}

Land demarcation is a fundamental requirement when determining to what extent property owners and public administrations can apply their rights. Just as international boundaries must be clearly marked so that there can be no doubt as to which jurisdiction is to be applied, municipal boundaries must be clearly defined in order to avoid disputes between local administrations.

In Spain the Geographical Institute carried out the demarcation of all municipal boundaries at the end of the $19^{\text {th }}$ and beginning of the $20^{\text {th }}$ centuries, defined their limits on cadastral maps and represented them on the 1:50,000 scale National Topographical Map.

At the present time, more than a hundred years after this survey, in many cases parts of the original municipal limits have been lost for one reason or another, both on the maps and on the ground itself, and it has now become necessary to take steps to recover them. This paper defines a method of using the municipal councils' own historical information to trace original boundary lines. The work included both a study and a series of tests carried out in different municipal areas in the Province of Valencia, Spain. The original reports and field notebooks of the Geographical Institute were used as the basic material of the study, supported by cadastral maps from different periods, as well as historical and contemporary orthophotos to help locate possible boundary markers. GPS techniques were employed to look for, survey and reinstate boundary marker positions.

\section{KEY WORDS}

Demarcation; boundary line; cadastre; cadastral map; historical map; municipal area 


\section{INTRODUCTION}

Territorial demarcation provides a means of defining the zone in which a state, a municipal district or even a private owner can exercise its/his rights (Grimalt, 2001). If this definition is not absolutely clear, there may be conflicts with neighbouring states (this situation has been the cause of no small number of wars), municipal districts or property owners. There have even been cases of a "postal struggle" for a territory (Reguera Rodríguez, 2007).

These problems have existed throughout history and still exist at the present time. Due to its considerable importance, many studies have been carried out on the subject of international frontiers based mainly on historical information, including, for example, the cases of The Belgian Congo and Northern Rhodesia (now Zambia) (Donalson, 2008a); Brazil, Peru and Bolivia (Valcuende del Río \& Cardia, 2009); the USA and Mexico (Kim, 2009; Casey, 2010); and Algeria and Tunisia (Blais, 2011). Other studies have dealt with the subject of frontier commissions (Donaldson, 2008b) or on the use of topographical features to define boundaries (Collier, 2009). There is, in fact, an organisation that specifically investigates international boundaries, known as the International Boundaries Research Unit of the University of Durham (http://www.dur.ac.uk/ibru).

Many of Spain's municipal districts have never been clearly defined, which means there are doubts as to the exact boundaries between different provinces and autonomous communities. This has led to conflicts with neighbouring states and other problems including territorial jurisdiction, as was the case with the Spanish colonial map of northern Morocco, in which the Ifni territory had not been clearly marked out (Urteaga, 2006).

The first topographical work in Spain on cartographic demarcation was carried out by the Military Archives Section of the Army General Staff (Urteaga, Nadal \& Muro, 2003). Later work included specific studies on the maintenance of the SpanishPortuguese frontier (Fernández Pareja \& García-Patos Herreros, 2012), inter-municipal cooperation in the Duero-Douro district (Manero Miguel, 2012) and on the SpanishFrench border (Capdevila i Subirana, 2009a, 2009b).

After an analysis of studies on neighbouring countries and colonies and the specific case of Spain, the subject of insufficiently defined inter-municipal boundaries within a single country is examined. Other authors have studied the situation in Spain and Columbia (Marínez Rivera, Díez Díaz, Buitrago, Olaya, Ladino, Duarte \& Mafla, 2006). To give some idea of the size of the Spanish problem, the country covers an area of approximately $505,000 \mathrm{~km}^{2}$ and has 8,100 municipal districts. In some cases, inter-municipal disputes have had to be settled in the law courts; like Order TER/2668/2009, of 24 August, approving the boundary between the municipal districts of Pinatar (Murcia) and Pilar de la Horadada (Alicante).

The competent authorities as regards the jurisdictional boundaries of municipal districts are the urban and rural councils themselves and any conflicts are referred to the corresponding Autonomous Communities. Different studies can be found from different periods in several Autonomous Communities. In the case of Cantabria, the work is carried out directly by the National Geographical Information Centre (CNIG; http://www.cnig.es) by an agreement with the Cantabrian Autonomous Government signed in 2009 (García Lario, Pérez Casas, 2010; Mañero García, 2012a; Mañero García, Piña García, García Lario \& Pérez Casas, 2012b).

Piña García dealt with the subject of administrative boundaries in his doctoral thesis (Piña García, 2009). The Catalonia Community recovered its historical municipal boundaries thanks to an agreement signed in 2005 between the Government and Public Administration Department and the Cartographic Institute of Catalonia (ICC; 
http://www.icc.cat) (Capdevila i Subirana, 2005; Massó, Torres \& Jiménez, 2011). García Cepeda (2009; Fábrega Golpe, García Cepeda, Luján Díaz \& Rubio Iglesias, 2008) carried out a study on the optimal methods of defining, updating, maintaining and use of jurisdictional boundaries, aimed at improving the information in the data bases of municipal boundaries (BDLL) of the National Geographical Institute (ING; http://www.ign.es) (Cruz Sánchez, 2011).

This aim of this work is to find solutions to inadequately defined municipal boundary lines in Spain in a study carried out in different zones in the Province of Valencia. Unlike previous studies, we propose a protocol which would enable the urban and rural councils themselves to take the initiative, and not the Autonomous Communities, who would only be called on to resolve conflicts.

\section{THE PROBLEM OF DEFINING MUNICIPAL BOUNDARY LINES IN SPAIN}

Defining boundary lines in a territory implies the existence of a previous demarcation process considered to be the official designation of the boundaries of a property. This operation leads to the definition of the jurisdictional limits of the property with regard to the boundaries of neighbouring properties (Femenia-Ribera, 2009). The demarcation itself and any other associated actions are carried out within the framework of an official demarcation procedure (Vilalta Nicuesa, 2005), after which the boundaries lines themselves are usually appropriately marked, although this is not always the case, as in the province of Cantabria.

In Spain at the present time there are official demarcation agreements that set out the dividing lines between different municipal areas. However, as these agreements were reached more than one hundred years ago, in many cases they have become obsolete for different reasons, such as: the different measuring techniques in use at the time, the disappearance of boundary markers, the lines have been transferred to smaller scale maps and are now unclear, or different municipal authorities may interpret the lines under different criteria. As Tucci and Giordano (2009) have pointed out, historical maps in general are less precise in positioning specific points than the present-day geographical data bases.

Nowadays boundary lines are represented in various ways by different organizations such as the IGN, the Dirección General de Catastro (DGC; http://www.catastro.meh.es) and the different local administrations. Also, on occasions the same organization has been found to represent lines differently at different times; a municipal area may draw the boundary lines with a neighbouring area in a certain place, while the neighbour may have drawn them in another (Femenia-Ribera, MoraNavarro, Benitez-Aguado \& Garrido Villén, 2013). This lack of reliable demarcation leads to jurisdictional conflicts between municipal councils and may be forgotten until the council wants to apply its building bye-laws or property taxes. In many cases the conflicts are settled in long drawn out court cases.

All the foregoing points to the need to define a clear and precise method of drawing up a legally valid and universally accepted set of boundary lines, the aim being not to create new lines, but rather to recover the original limits drawn up with the collaboration of the municipal councils involved.

Official demarcations drawn up by the Geographical Institute at the end of the 19th and beginning of the 20th centuries.

At the end of the 19th and beginning of the 20th centuries, the IGN carried out the official demarcation of all Spanish municipal areas, with the approval of the municipal authorities concerned. The National Topographical 1:50,000 Scale Map was used for this purpose and the perimeters were also marked in the cadastral maps (Urteaga, 2008; Berne Valero \& Femenia-Ribera, 2000). 
The same boundary lines are in use today since they are still the official municipal borders and are consulted when there is a conflict between municipal councils due to missing boundary markers.

The information obtained in the course of this work was in the form of the demarcation documents themselves and the field notebooks belonging to the members of the working group (Femenia-Ribera, 2006). The original paper documents can be seen in the Technical Archives of the IGN's Servicio de Documentación y Biblioteca. Digital copies can be consulted in the IGN's regional services in the different autonomous communities. All the information is managed by a system known as the SIDDAE GIS and the free GIS system gvSig (Cruz Sánchez, 2010).

1. Demarcation documents and field notebooks

-The demarcation documents describe the location of boundary markers in relation to nearby features (Figure 1) as well as the geometry of the boundary lines. They are considered to be the definitive official documents, since they were signed at the time by the municipal authorities concerned.

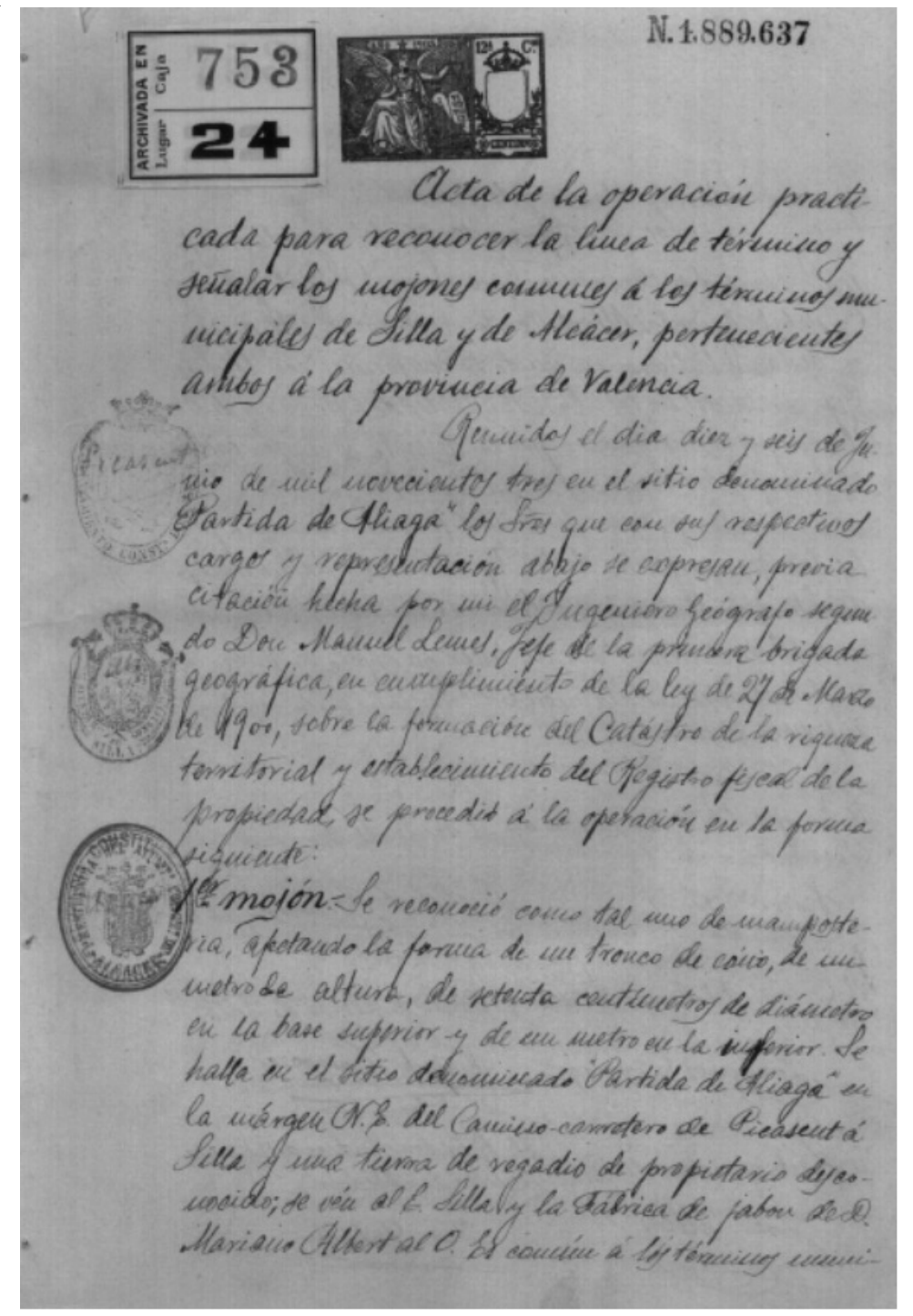

Fig. 1. Extract from a demarcation document relating to the Silla-Alcàsser municipal areas in 1903. Source: IGN, Regional IGN Service in the Community of Valencia [hereafter IGNV]

-The field notebooks contain the technical information used by the group to draw the boundary lines on the maps (Figure 2) and include: base points, observed points, compass headings in sexagesimal graduation, distances measured by measuring rods, 
depression and elevation angles, slope calculations, and sketches including distances to neighbouring objects.
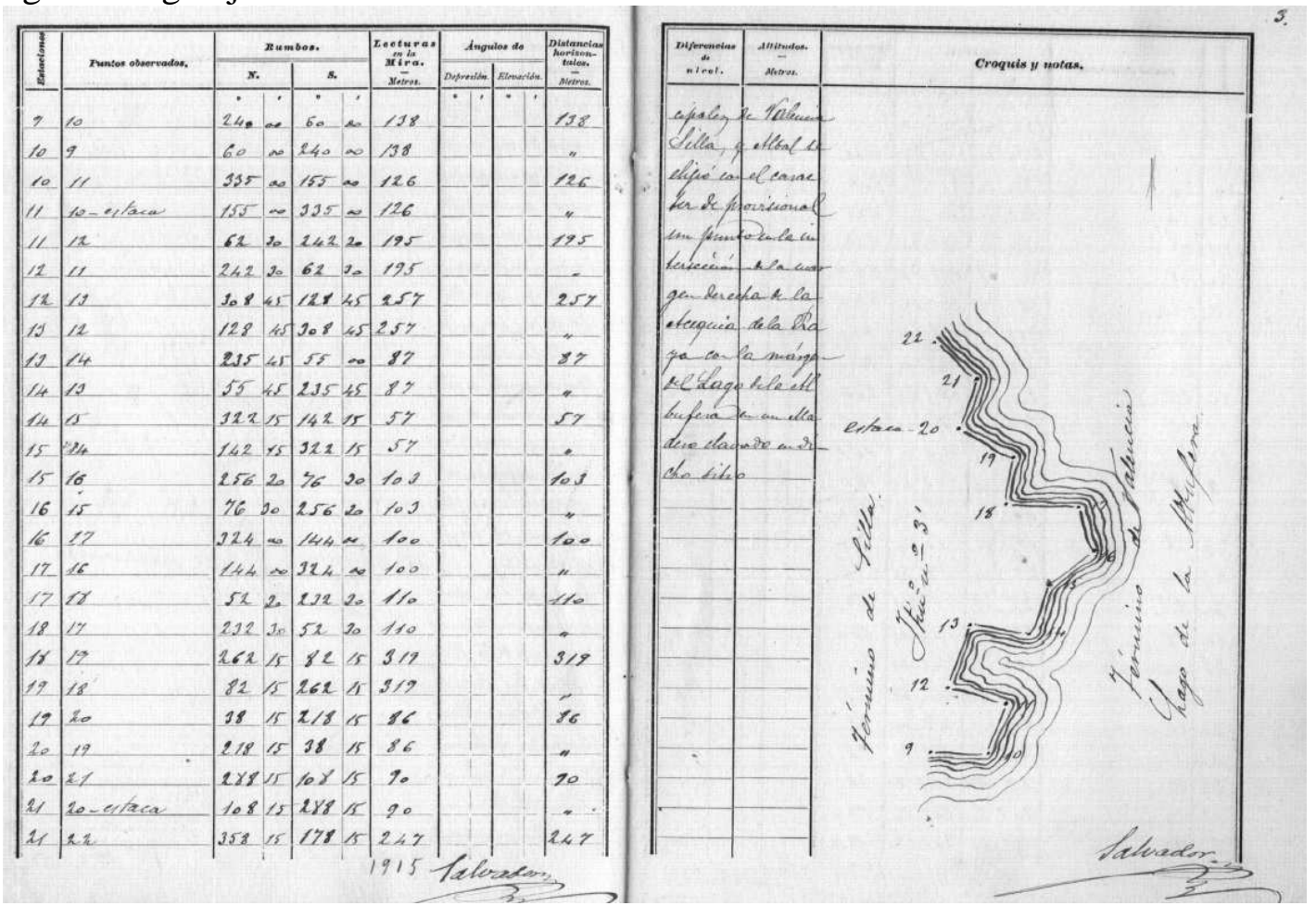

Fig. 2. Extract from a field notebook; Valencia-Silla municipal areas, 1903 Source: IGNV

\section{Historical cadastral maps: topographical cadastral maps}

From the original information obtained from the demarcation documents and field notebooks, the perimeters of the cadastral units, or municipalities, were drawn to form the graphic basis of the planimetric maps, or geometric geographical maps (Pro Ruíz, $1992,1999)$. These maps represented the set of boundary markers described in the demarcation documents and defined in technical terms in the field notebooks (Figure $3)$.

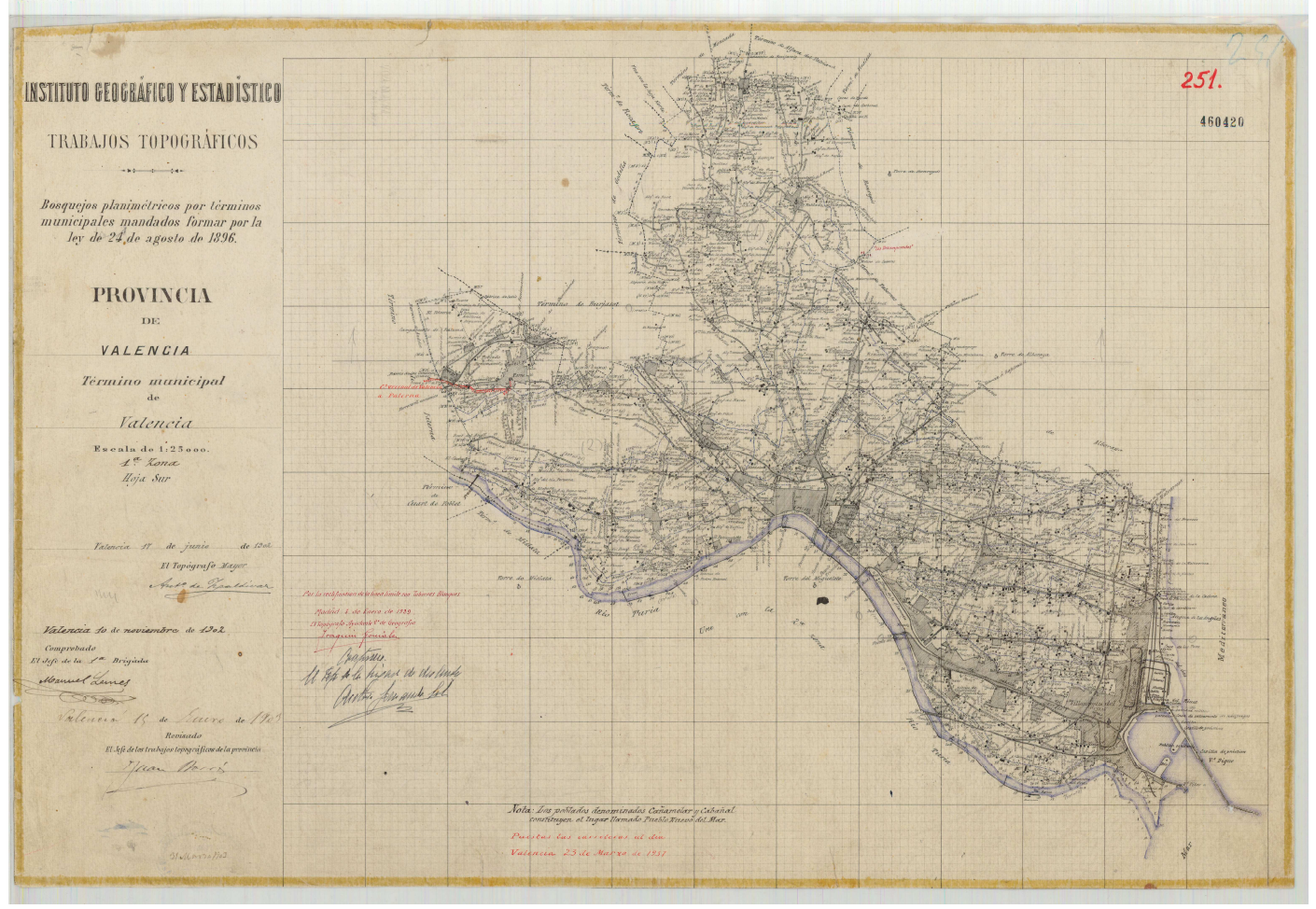


Fig. 3. 1:25.000 planimetric map. First zone of the Municipality of Valencia, 1902. Source: IGN central office

This planimetric map, generally on a scale of 1:25,000 but occasionally $1: 50,000$, contain drawings of the different rustic polygons into which the cadastral maps were divided and are regarded as a type of map. The polygons, in turn, are independent maps on a scale of 1:2,000 or 1:5,000 that show all the cadastral parcels and are at present to be found in the GGC's regional offices (Moya Rodríguez \& García-Rodrigo Martín, 2002; Alcàzar Molina, 2003), with copies in the IGN. The originals of these maps were based on the boundary lines contained in the demarcation documents. They were hand-painted on squared paper and besides the cadastral parcels contained topographical polygons for technical calculations and drawn on thick squared cardboard and also showing topographical itineraries (Fig.4) ( Berné Valero, FemeniaRibera \& Aznar Bellver, 2004; Berné Valero, Femenia-Ribera, Benitez-Aguado, 2008)

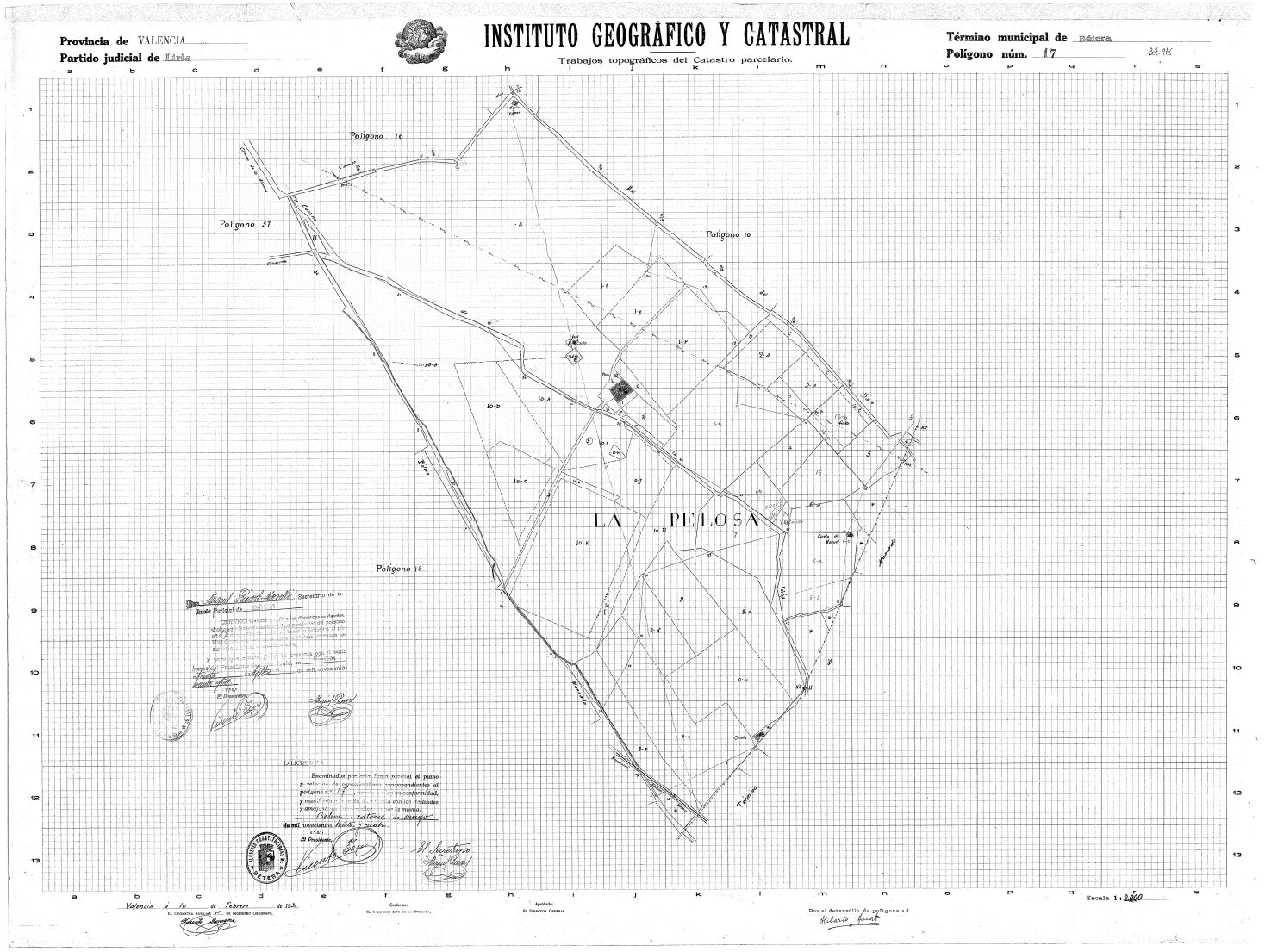

Fig. 4. Black and white copy of the original 1:2,000 scale cadastral map Polygon 17, Bétera Municipality, 1931. Source: Bétera Town Council

The information was copied from the original cadastral map, leaving out the technical data, giving rise to the Parcels Topographical Map (MTP in Spanish) generated for each of the polygons (Figure 5). The municipal boundary lines are drawn in the polygons touching on other municipalities and each of the boundary markers defined in the demarcation documents is shown with the numbers MX (X being the marker number). 


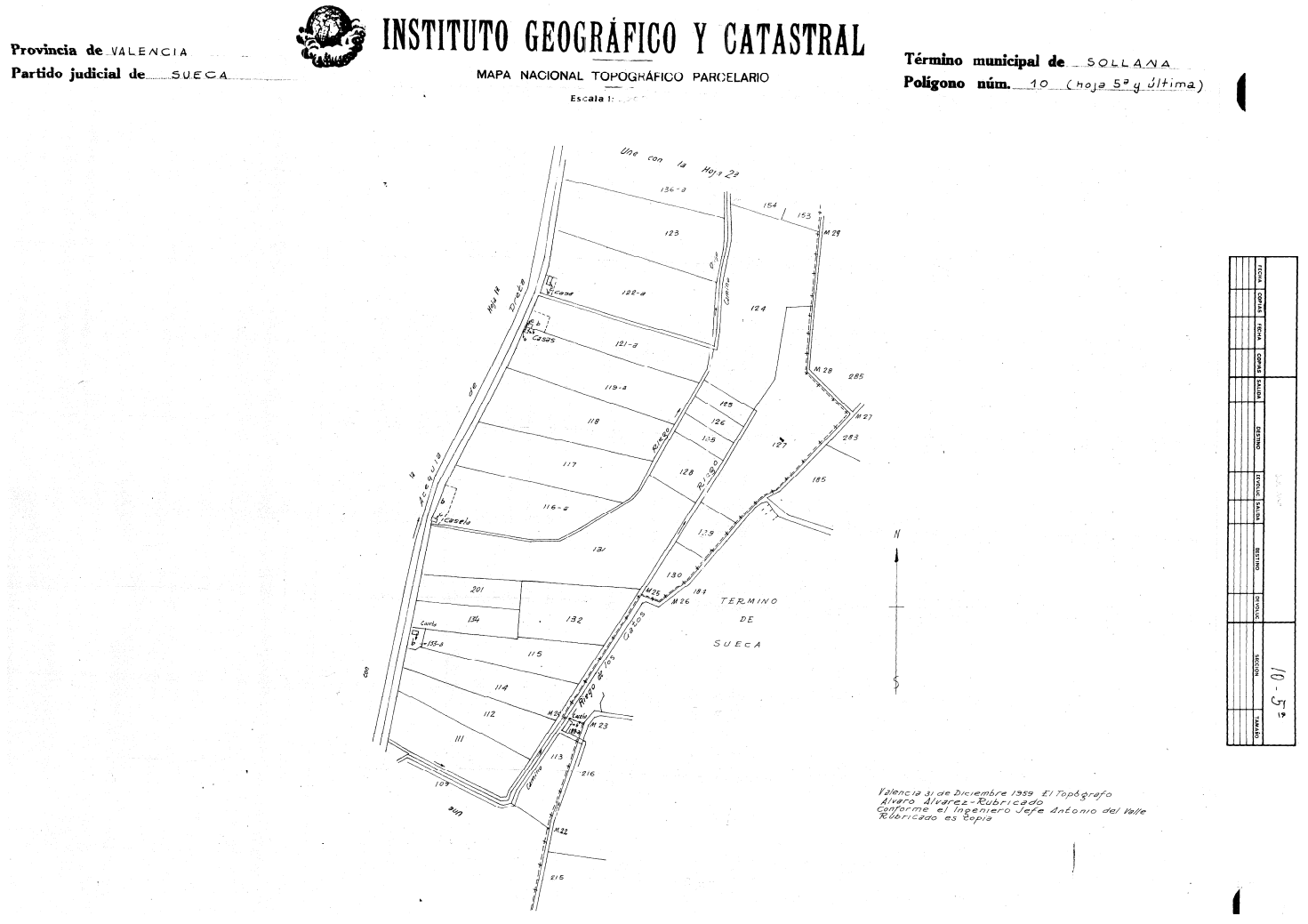

Fig. 5. 1:2.000 MTP. Polygon 10, Sheet 5, Sollana Municipality, 1959. Source: IGN Central Office

\section{RECOVERY OF MUNICIPAL BOUNDARY LINES}

As many boundary markers have now disappeared, the present limits cannot always be physically identified on the ground. However, it is not possible to use the boundaries drawn on the cadastral map to locate the markers, due to the conflicting lines placed at different times by different administrations. It is therefore necessary to recover the official demarcation from the set of markers as defined on the demarcation document in order to put them in their right place on the ground.

The original documents must be studied, interpreted, translated technically and adapted to the current measuring techniques in order to create new demarcation documents. This work requires a number of steps to be followed in recovering and interpreting the information on the part of the municipal authorities interested in determining the precise location of their boundary lines. The cost of applying the proposed procedure is relatively low and the decision lies with the town and urban councils, who are the competent authorities in this case. In order to validate the method proposed in this paper, a series of tests were carried out in a number of municipal areas in the Province of Valencia (in the Community of Valencia) during a period of approximately three years.

Municipal areas in the Province of Valencia, Spain, involved in the study

The municipalities that took part in the present study were: Casinos, Valencia, Moncada, Bétera, Picassent, Náquera, Alcàsser and Algemesí, some of which are adjoined to each other, as in the case of Picassent and Alcàsser (Figure 6). The first test were carried out in the Municipality of Moncada (Cazallas Delfa, Rivera Lacomba, Femenia-Ribera \& Rodrigo Pascual, 2010). In most cases, the entire perimeter length was examined and in others we limited the study to only a part of its length. 


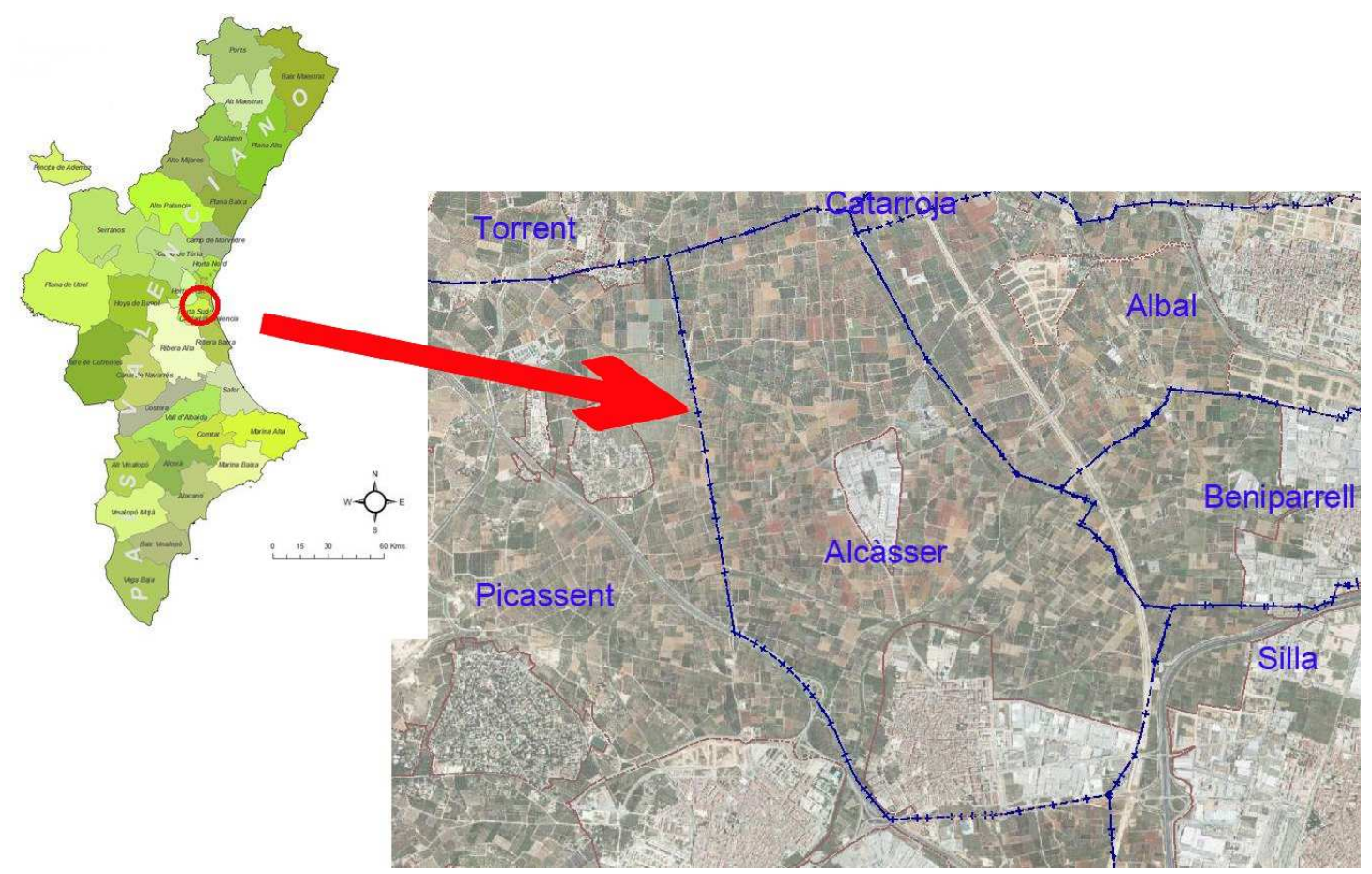

Fig. 6. Positional map of the Alcàsser Municipality, Community of Valencia, east of Spain. Source: Compiled by the authors from IDEE cartography; http://www.idee.es

The following section deals with the method used to recover the original boundary markers. A combination of the historical cadastral cartography and modern GPS measurements was used to obtain a high degree of precision. This type of work is considered ideal for Spanish land surveyors, due to their previous experience in this field (Aguña Martín, 2000; Femenia-Ribera \& Soriano Hernández, 2005a, 2005b; Garrido-Villen, Anton-Merino, Berne-Valero \& Femenia-Ribera, 2013).

\section{Obtaining the documents and preliminary analysis}

The first step in the process is a preliminary study of the original demarcation documents, field notebooks and planimetric maps for each municipality, with additional information on the cadastral polygons from both the original cadastral map and the MTP. This information is available at both the IGN headquarters and its Valencia branch (IGNV). The polygons can be found either at the DGN offices or in some cases in historic archives. In Valencia the cadastral maps can be seen in the archives of the Archivo del Reino de Valencia (AHRV; http://dglab.cult.gva.es/ArxiuRegne), and in some cases copies are available at the local town halls.

Local orthophotos can be used as complementary resources to help to identify boundary markers and also to join up the field notebook itineraries. For the present study we used orthophotos belonging to the Valencia Cartographic Institute (Instituto Cartográfico Valenciano (ICV; http://www.icv.gva.es) taken by the National Aerial Orthophoto Plan (Plan Nacional de Ortofotografía Aérea (PNOA)), in Valencia (http://www.citma.gva.es.).

The next step was to interpret and transpose the material in the field notebooks. Compass traverse techniques were used to obtain the polygons, which were fitted geometrically to the available orthophotos. This information was checked by reference to the descriptions in the demarcation document and any other available documentation, such as cadastral maps, planimetric maps MTP or other types of map available. After this, initial approximate coordinates could be obtained to locate on the ground the markers described in the original documents. 


\section{Field visits to find existing boundary markers}

The rough coordinates were used to find the surviving boundary markers. The equipment used in the search included GPS navigator with the coordinates entered, an orthophoto of the zone with the estimated position of the marker, sketches from the field notebooks and the demarcation document. Additional documentation could also be useful for a more exhaustive search in case the first turns out to be fruitless. It should be borne in mind that the demarcation document takes priority over any topographical document and should always be at hand in the field to check the final results and whether the marker located is in fact the one that was being searched for.

\section{Types of boundary marker}

The types of boundary marker were found to vary from one area to another with respect to their placement, the year in which they were produced and any repairs carried out on them. They had been built in accordance with the descriptions in the demarcation documents (Benitez-Aguado, 2007b). The sizes also varied and some reached as high as two metres (Figure 7). In some cases, the markers were found to have been erected before the demarcation documents had been completed.

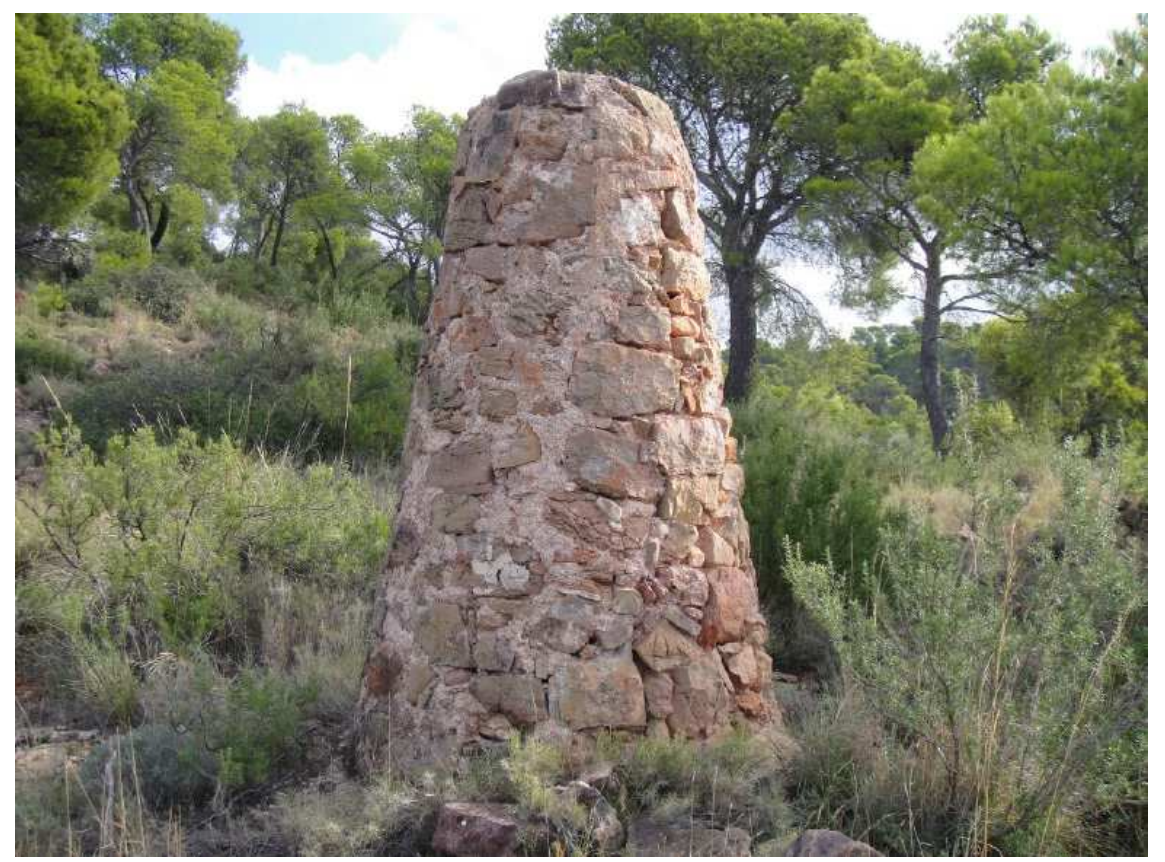

Fig. 7. Boundary marker in the Náquera Municipality

\section{Surveying existing markers by GPS}

As pointed out by Brumec and Kolesa (2011), boundaries on cadastral maps must be consistent and it is therefore necessary to use the same reference system when taking topographical measurements. The markers successfully located were thus surveyed by GPS techniques in order to obtain the definitive coordinates (Figure 8) in ETRS89, UTM projection and the corresponding time zone of the Spanish and European official reference system (See Royal Decree 1071/2007, 27 July, regulations on the oficial Spanish geodesic reference system. BOE, 29 August, 1970 ( $N^{\circ} 172 / 2007$ p. 35986)).

The Real Time Kinematic GPS (RTK GPS) method, widely used in topographical work, was used to survey the boundary markers. This equipment has been found to give results as good as the traditional surveying methods, as Pirti et al have pointed out (Pirti, Arslan, Deveci, Aydin, Erkaya \& Hosban, 2009). It is especially useful in measuring long distances, as was the case in the present study. However, it is on occasions necessary to use classical topographical instruments in areas in which GPS cannot guarantee the required precision, as for example in wooded areas. 


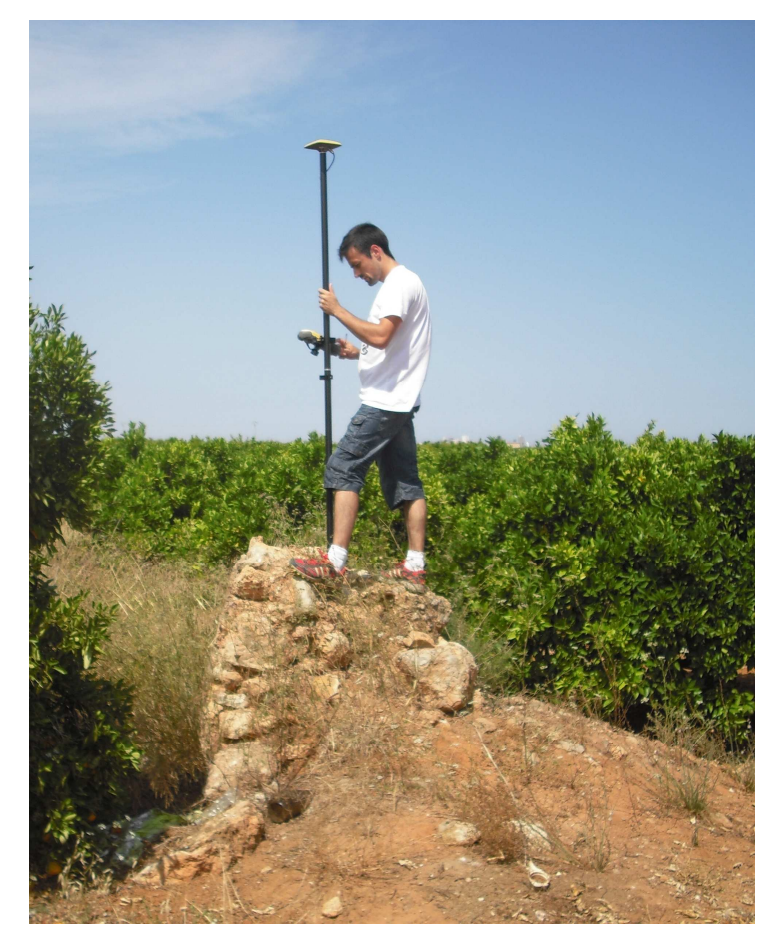

Fig. 8. Surveying a boundary marker by GPS in the Alcàsser Municipality

The numbering of the markers must be consistent with the data contained in the demarcation documents. The first marker should be designated M1, the second M2, etc. up to MX for the last one described in the document. When a marker touches on three different municipal areas, it should be indicated as MX $=$ M3T. The auxiliary points of non-straight lines also have their own numbering system.

\section{Recovery of markers}

When all the possible markers have been identified, any that are still missing are assumed to have disappeared in the course of time. Special care should be given to those cases in which a nearby marker does not coincide exactly with the information in the demarcation document. In such cases it can be assumed to have been moved from its original position and classed as another marker that needs to be recovered. Recovering markers involves obtaining a set of accurate new coordinates and this information can be used to put replacement markers in their correct positions by GPS techniques. These sites are temporarily signalled by non-permanent markers.

1. Obtaining coordinates from topographical cadastral maps

The most likely position of missing boundary markers can be determined from the information contained in the demarcation documents. This is done by performing the compass traverse as described in the field notebooks, followed by geometrical fitting on orthophotos in accordance with the documents. This fitting is repeated after obtaining the definitive coordinates of the surviving boundary markers. All this information is supported by all the available maps, especially by the MTP. AutoCad is the main graphic editing tool (Figure 9) used to fit maps together, with the assistance of the free GIS gvSIG (Figure 10). 


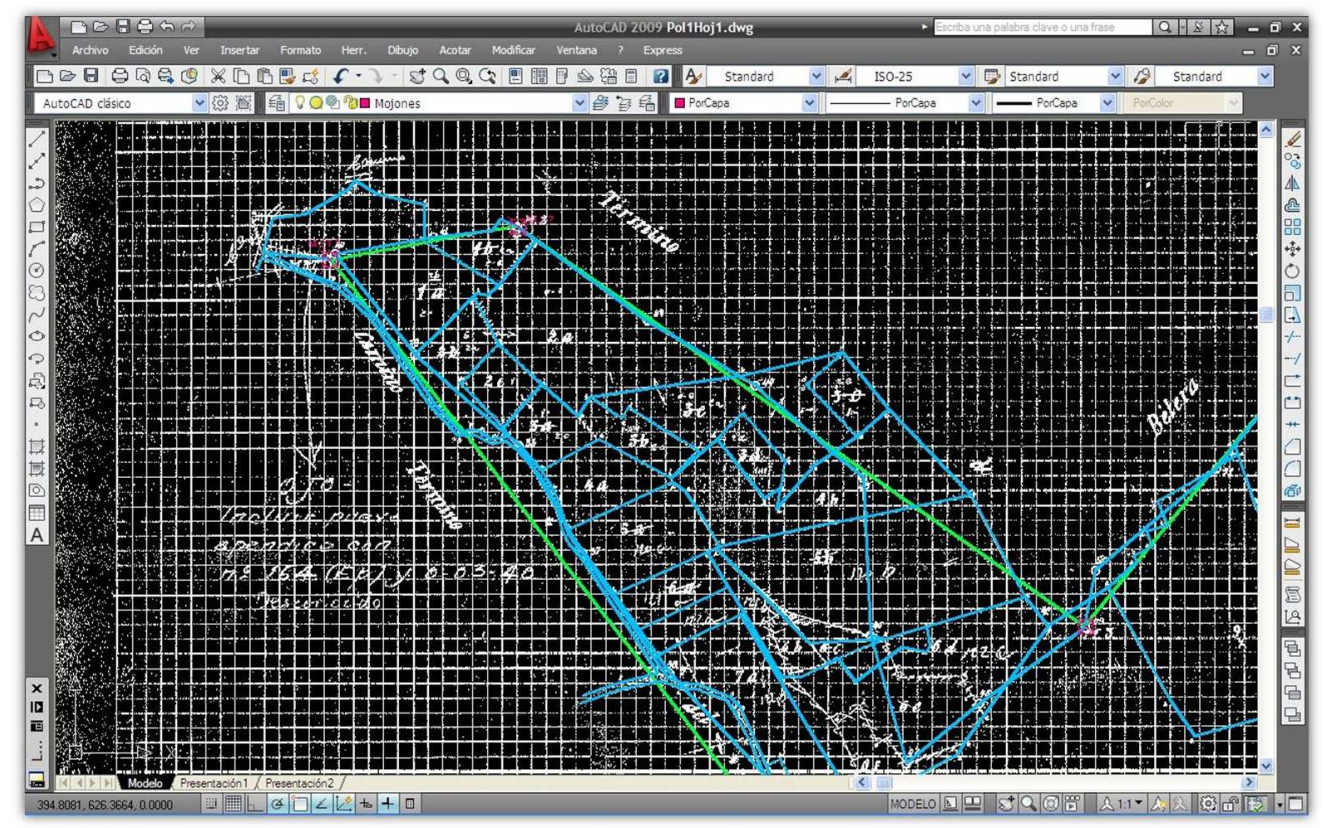

Fig. 9. AutoCad graphics editor: cadastral map of Moncada municipality drawn from compass traverse and topographic fitting. Source: compiled by the authors with information from Moncada Town Council

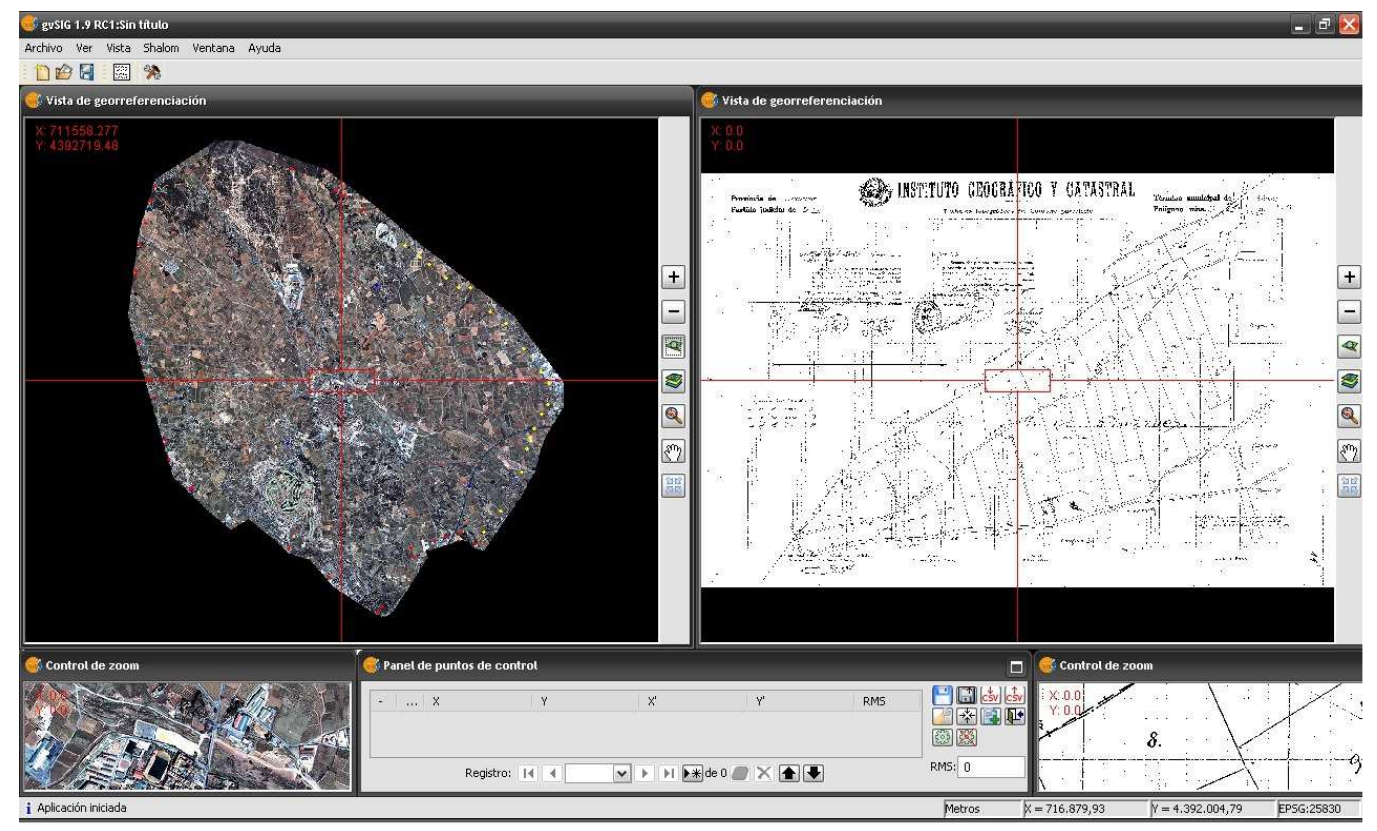

Fig. 10. Free GIS gvSIG: orthophoto and the topographical cadastral map of Bétera municipality. Source: Compiled by the authors with information from Bétera Town Council

The final coordinates of the missing markers were obtained from the above set of topographically fitted maps and were then used to re-draw the boundary lines on the ground with the help of GPS (Benitez-Aguado, 2007a).

\section{Reinstating boundary markers by GPS techniques}

RTK GPS (Real Time Kinematic GPS) was also used to re-site the missing boundary markers. This system has been shown to be sufficiently accurate for this purpose by Jarroush and Even-Tzur (2006). As in the survey of the surviving markers, the accuracy required is to within $0.1 \mathrm{~m}$ using the ETRS89 reference system and UTM coordinates. The final result is the set of definitive coordinates of the surviving and reinstated markers (Figure 11). 


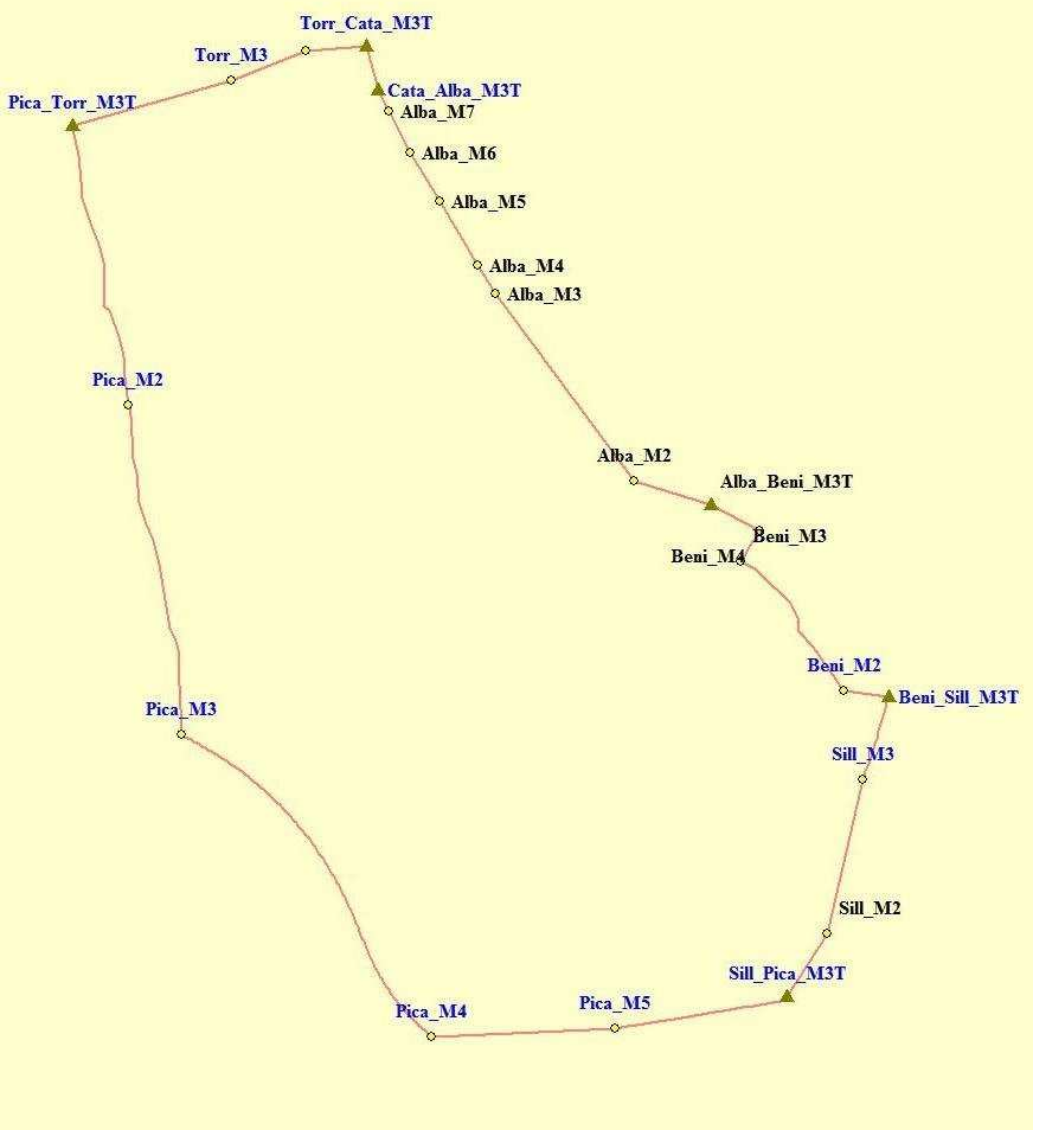

Fig. 11. Map showing the position of surveyed and re-sited boundary markers in the Alcàsser municipality. Source: Compiled by the authors

\section{Creating the final maps and information boxes}

The complete set of the information obtained is used to draw a map of the municipal area on a PNOA orthophoto, including the definitive boundary lines and the surveyed and re-sited markers (Figure 12).

Fig. 12. Final map of boundary lines with markers of the Moncada municipality on an orthophoto. Source:

Compiled by the authors

The most important information is contained in the information boxes associated with each of the markers, including an exact description of each one together with its coordinates. This information will make it possible to locate its exact position at any time in the future. The boxes contain the following information: name of municipality, name of marker, geodesic and UTM coordinates, date of survey/re-siting, method used, cadastral reference and site of the cadastral parcel in which it is situated, directions to preceding and following markers, literal description, photo, sketch of position, boundary line and markers on an orthophoto, copy of demarcation document, and identification on MTP. (Figure 13 and 14). Also included is a report containing a detailed description of the technical procedures carried out. 

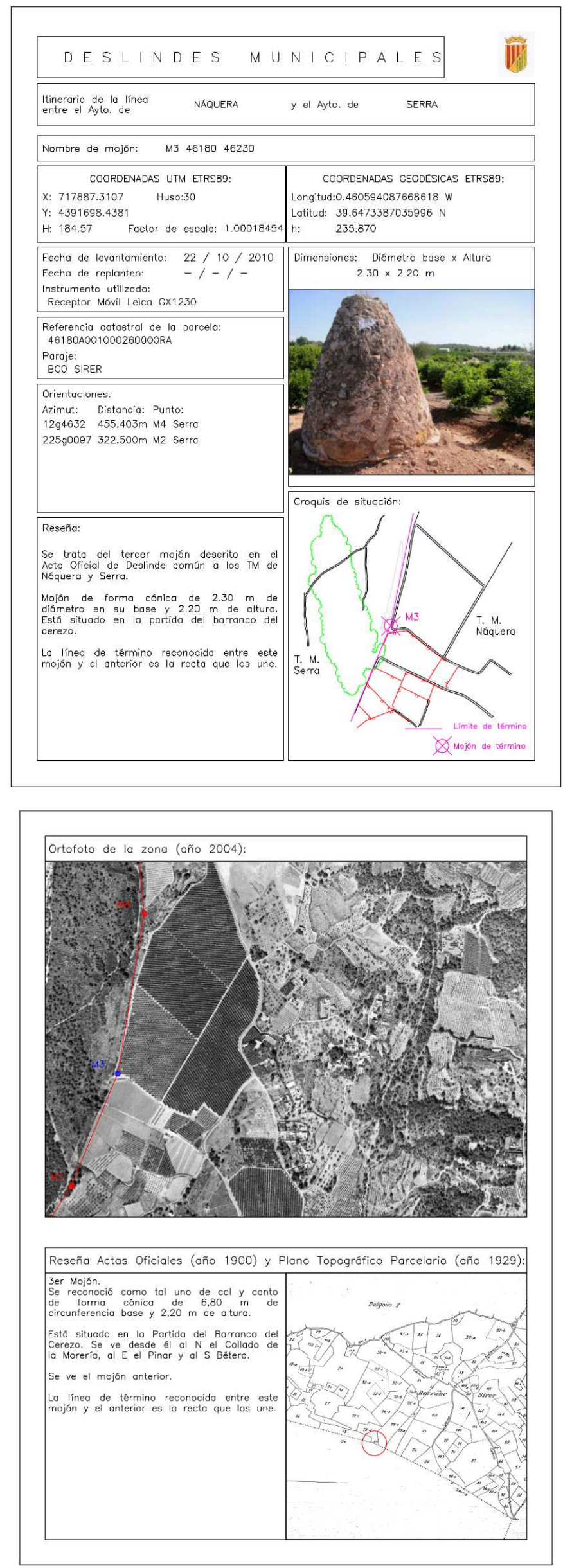
Figs. 13 and 14. Information box of a marker on the boundary between the Náquera and Serra municipalities. Source: Compiled by the authors

\section{Legal validity of reinstated boundaries}

The inter-municipal boundaries recovered in this way do not become valid until they have received official recognition in the form of the approval of the municipal authorities involved. The technical aspect must be accompanied by the legal aspect. As Forman (2006) pointed out in his study carried out in Israel, legislation plays an important role in marking out territories, with space and law being mutually interdependent.

The results of the study are therefore transmitted to the municipal demarcation commissions appointed for this purpose in each of the town councils concerned. This report basically involves the markers in the reinstated boundary lines and if it is considered to be appropriate a visit is made to the site and they are approved en situ. Additional demarcation documents are then drawn up to be added to the originals for the approval of the demarcation commissions and later by the full municipal council, after which the lines become legally valid.

For this information to be added to the official cartography, it must previously be inscribed in the Central Cartographic Register (RCC; http://www.fomento.gob.es/MFOM/LANG_CASTELLANO/DIRECCIONES_GENE RALES/INSTITUTO_GEOGRAFICO/REG_CENTRAL_CARTO and http://www.ign.es/ign/layoutIn/registroCartografico.do) of the Consejo Superior Geográfico

(CSG; http://www.fomento.gob.es/MFOM/LANG_CASTELLANO/ORGANOS_COLEGIA DOS/CSG) of the IGN and also in the Register of Local Entities (Law 7/1986, 24 January, Regulations on Cartography; and Royal Decree 1545/2007, 23 November, regulating the National Cartography. Chapter IV. Registro Central de Cartografía. Sección $2^{\mathrm{a}}$. Delimitaciones Territoriales. Artículo 20).

\section{RESULTS}

In the course of the study, from the preliminary searches in the town halls to the final checks in the IGN, we made progressive changes to the method initially proposed. We were finally able to draw up an action protocol and design a set of standard documents, including: additional demarcation documents for inter-municipal boundaries, a model table for marker coordinates and waypoints, and a standard marker information box.

As a result of the preliminary studies and the subsequent exhaustive analysis carried out in the IGNV, we developed a protocol which can be used as a guide by any town council that wishes to recover its original boundary limits. This work fundamentally involved the IGNV, different specialists (mainly land surveyors), various autonomous and local administrations, and final approval was given by the IGN, as the aim was to make a protocol suitable for use throughout Spain.

The final result is in the form of the document "Protocol and necessary technical conditions for the recovery and correction of legal boundaries within the Community of Valencia" developed by the IGNV under the aegis of the IGN and the Ministry of Development. It's on the official website IGN (http://www.ign.es/ign/layoutIn/protocoloRcc.do; in Spanish).

The work of recovering boundary lines can also be applied to the cadastre, since the information obtained is fundamental for the exact definition of the cadastral action unit, i.e. the municipality. This information is entered in cadastral GIS (SIGCA2) (Conejo Fernández \& Virgós Soriano, 2001). An example can be seen in Figure 15, showing the Casinos Municipality. It is also published in the Cadastral Electronic Webpage (Sede Electrónica del Catastro (SEC; http://www.sedecatastro.gob.es)). 


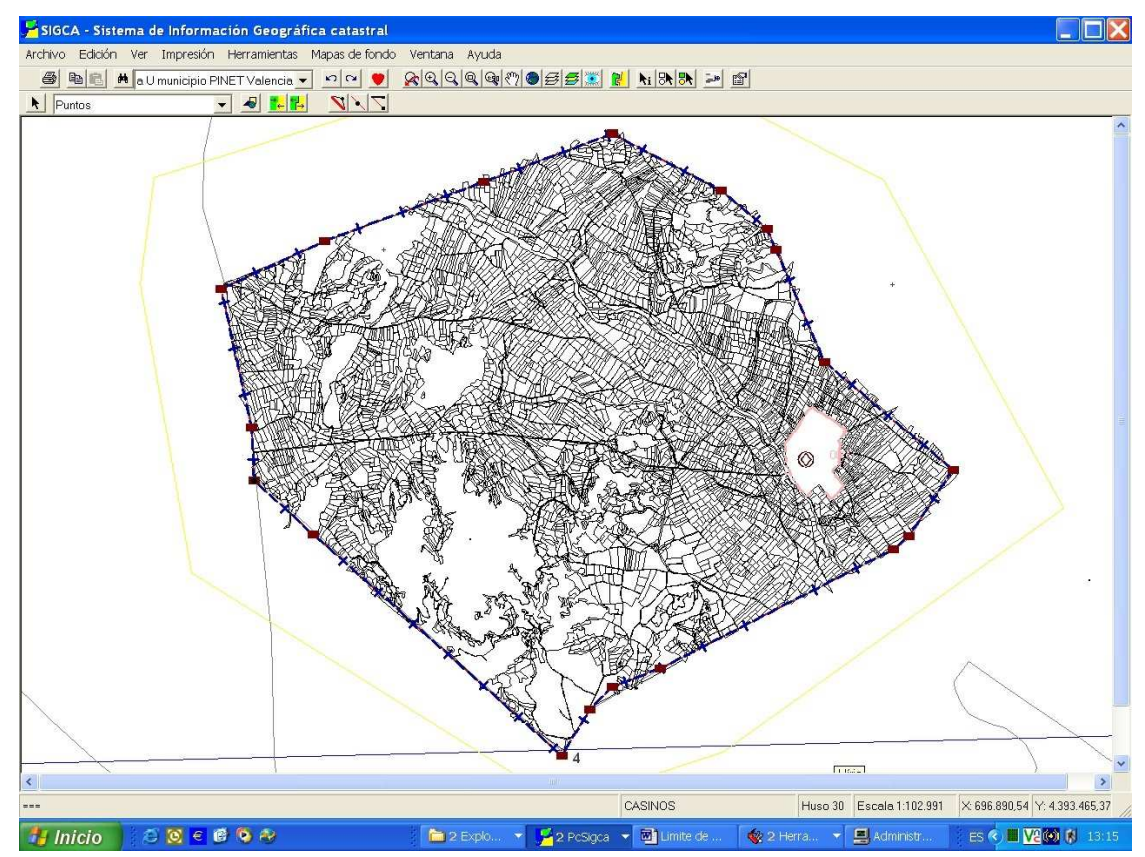

Fig. 15. Line in SIGCA2. Casinos Municipality. Source: Dirección General del Catastro: Gerencia de Valencia

\section{Conclusions}

The method proposed in the present paper offers a simple and efficient solution to the problem of unclear boundary lines between municipal areas. It is adapted to the current Spanish legislation in respect to both cartography and jurisdictional competencies and can be applied to municipalities within a single autonomous community or to those belonging to different communities.

The method was analysed and applied to municipalities in the Province of Valencia, but could also be used without previous modifications, apart from questions of different regulations between autonomous communities, to any municipality in Spain.

The study described here was developed from two distinct perspectives, fundamentally technical but without forgetting the juridical aspect, which is an indispensable part of the process for the legal recognition of newly recovered boundary lines. It should also be remembered that if an existing boundary line has to be modified it is necessary to apply another procedure in line with the current legislation, since in this case it is only valid as a complement with additional demarcation documents, as well as the originals. However, a large part of the method can be used as an example in any case of defining boundary lines between different administrations, including the design of the demarcation documents, the coordinate tables and standardized information boxes

As every local administration is competent in matters regarding its own boundary limits, it is possible for a town hall to take the initiative and define its boundaries without initially consulting other administrations, although in the final stages of approving the boundary the consent of the neighbouring municipalities does become necessary. Also, a town hall can order a review of its complete boundary or of any part of it. From the financial point of view, the whole process can be regarded as reasonably priced and the costs can be further reduced by sharing the work with neighbouring municipalities. Most of the financial cost is due to the technical work involved in the process, even though this usually lasts only a few weeks. As the judicial aspect is more complicated, it is often a slow process, especially if agreements have to be reached with others and the documents must be approved by the plenary council, which may take up to several years. 


\section{ACKNOWLEDGEMENTS}

The authors are grateful for the support and collaboration received from Sr. Fernando Cruz Sánchez (Director of the Servicio Regional del Instituto Geográfico Nacional in the Community of Valencia, Spain). Our thanks are also due to Sr. Jesús Pla Hontoria (Land Surveyor of the Instituto Geográfico Nacional) for his contribution to the development of this work. We would also like to acknowledge the support and collaboration received from the management of the Catastro de Valencia and from the Land Surveyors: Ana, Laia, Ana $\mathrm{M}^{\mathrm{a}}$, Roberto, Carlos, Vicente, Vicent, Jorge, Antonio, Marcos, Carlos, Alberto, Laura and Álvaro.

This work has been partially supported by the research project "The Land Registry as the basic tool for organising spatial information; INSPIRE Directive, spatial data and metadata (II)", DER2011-23321 from the Spanish Government.

The translation of this paper was funded by the Universitat Politècnica de València.

\section{References}

Alcázar Molina, M., 2003. Catastro Inmobiliario. Centro de Ingeniería Económica (INECO) Editorial Universidad Politécnica de Valencia ref. 2003-2176.

Benitez-Aguado, E., 2007a. Replanteo de líneas límite en planos de Catastro a partir de mapa topográfico parcelario. Revista CTCatastro, 60, 71-87.

Benitez-Aguado, E., 2007b. Deslinde y amojonamiento de términos municipales. Revista CTCatastro 60, 91-107.

Berné Valero, J.L. and C. Femenia-Ribera, C., 2000. Catastro de rústica. Editorial Universidad Politécnica de Valencia ref. 2000-4185, 386.

Berné Valero, J.L., Femenia-Ribera, C. and Aznar Bellver, J., 2004. Catastro y Valoración Catastral, Editorial Universidad Politécnica de Valencia ref. 2004-532.

Berné Valero, J.L., Femenia-Ribera, C. and Benitez-Aguado, E., 2008.Catastro en España, Editorial Universidad Politécnica de Valencia ref. 2008-413, 550.

Blais, H., 2011. An intra-imperial conflict: the mapping of the border between Algeria and Tunisia, 1881-1914. Journal of Historical Geography, 37, 178-190.

Brumec, M. and Kolesa, K., 2011. Land Cadastral representation adjustment when making land survey plan. Geodetski vestnik 55/2, 284-291.

Capdevila Subirana, J., 2005. Els treballs de delimitació municipal del Instituto Geográfico Nacional a Catalunya, 1909-1930, Treballs de la Societat Catalana de Geografia, 60, 45-69.

Capdevila i Subirana, J., 2009a. Historia del deslinde de la frontera hispano-francesa. Del tratado de los Pirineos (1659) a los tratados de Bayona (1856-1868). Instituto Geográfico Nacional-Centro Nacional de Información Geográfica, 184.

Capdevila i Subirana, J., 2009b. Qui va dibuixar la ratlla? Treballs de la Comisión Mixta de Límites (1853-1868). Congrés El Fet Fronterer. Fronteres, relacions, intercanvis, Institut d'Estudis Empordanesos, Figueres.

Casey. E.S., 2010. Border versus boundary at La Frontera, Enviroment and planning. D, Society and space, 29, 384-398.

Cazallas Delfa, C., Rivera Lacomba, R., Femenia-Ribera, C. and Rodrigo Pascual, V., 2010. Metodología de definición de la línea de Término Municipal mediante técnicas GPS, Revista TopCart XXVII, 14-20.

Collier, P., 2009. International boundary surveys and demarcation in the late 19 th and early $20^{\text {th }}$ centuries. Survey Review, 41, 2-13.

Conejo Fernández, C. and Virgós Soriano, L.I., 2001. SIGCA2: Cartografía catastral digital, disponible para todos. Revista CTCatastro, 42.

Cruz Sánchez, F., 2010. Líneas límite en la Comunidad Valenciana, Colegio Oficial de Ingenieros Técnicos en Topografía. Valencia. 
Cruz Sánchez, F., 2011. Determinación de líneas límites, Primeras Jornadas de Arquitectura e Ingeniería Civil y Cartográfica de la Comunidad Valenciana. Valencia.

Donaldson, J.W., 2008a. Pillars and perspective: demarcation of the Belgian Congo-Northern Rhodesia boundary. Journal of Historical Geography, 34, 471-493.

Donaldson, J.W., 2008b. Politics and scale in boundary-making: the work of boundary commissions, Journal of Historical Geography, 34, 393-396.

Fábrega Golpe, J.M., García Cepeda, F., Luján Díaz, A.M. and Rubio Iglesias, J.M., 2008. Metodología para la optimización de la base de datos de líneas límite del Instituto Geográfico Nacional, Uned. Espacio, Tiempo y Forma, Geografía 1, serie VI, 93-104.

Femenia-Ribera, C. and Soriano Hernández, V., 2005. Deslindes y Servidumbres: El papel del Ingeniero Técnico en Topografía (I). Revista TopCart, 126, vol. XXI, 16-25.

Femenia-Ribera, C. and Soriano Hernández, V., 2005. Deslindes y Servidumbres: El papel del Ingeniero Técnico en Topografía (II). Revista TopCart, 127, vol. XXII , 17-23.

Femenia-Ribera, C., 2006. La topografía y la cartografía en los deslindes y servidumbres en España, Biblio 3W: Revista bibliográfica de Geografía y Ciencias Sociales, 10, 100-110 <http://www.ub.edu/geocrit/b3w-666.htm> Retrieved 10.07.13.

Femenia-Ribera, C., 2009. La Cartografía y su Legislación Territorial. Editorial Universidad Politécnica de Valencia ref. 2009-505, 272.

Femenia-Ribera, C., Mora-Navarro, G., Benitez-Aguado, E. and Garrido Villén, N., 2013. A study and analysis of ways of representing the boundary between adjacent municipal areas as used in different types of maps in Valencia wetland. Scripta Nova. Revista electrónica de geografía y ciencias sociales. In press.

Fernández Pareja, M.T. and García-Patos Herreros, P.J., 2012. International Border Agreements: Spanish-Portuguese Model. X Congreso TopCart 2012: Congreso IberoAmericano de Geomática y Ciencias de la Tierra, Madrid.

Forman, G., 2006. Law and the historical geography of the Galilee: Israel`s litigatory advantages during the special operation of land settlement. Journal of Historical Geography, 32, 796-817.

Garrido-Villen, N, Anton-Merino, A., Berne-Valero, J.L. and Femenia-Ribera, C., 2013. Land surveyors as expert witnesses en real estate litigation matters in Spain. Geodetski Vestnik, 57, 66-84.

García Cepeda, F., 2009. Doctoral Thesis: Optimización de la metodología para la definición, actualización, mantenimiento y aprovechamiento de las líneas límite jurisdiccionales. Departamento de Ingeniería Topográfica y Cartográfica. Universidad Politécnica de Madrid.

García Lario, J.M. and Pérez Casas, J.M., 2010. Delimitaciones Territoriales, Centro Nacional de Información Geográfica, Curso Básico sobre el Sistema Cartográfico Nacional. Valencia.

Grimalt Servera, P., 2001. El Deslinde entre Particulares. Editorial Aranzadi.

Jarroush, J. and Even-Tzur, G., 2006. Re-instating parcel boundaries by real time kinematic GPS. Survey Review, 38, 643-653.

Kim, M.A., 2009. The imaginarium Line: A History of the United States and Mexican Boundary Survey, 1848-1857. Hispanic American Historical Review, 89, 196-197.

Manero Miguel, F., 2012. La cooperación intermunicipal como estrategia de ordenación y desarrollo territorial en espacios transfronterizos: La agrupación europea de cooperación territorial Duero-Duoro. Boletín de la Asociación de Geógrafos Españoles, 58, 249-272.

Mañero García, A., 2012a. Plan Nacional de Referenciación Geográfica Municipal, Centro Nacional de Información Geográfica. Curso Básico sobre el Sistema Cartográfico Nacional. Valencia.

Mañero García, A., Piña García, F., García Lario, J.M. and Pérez Casas, J.M., 2012b. Actualización de las delimitaciones territoriales en Cantabria, X Congreso TopCart 2012: Congreso IberoAmericano de Geomática y Ciencias de la Tierra. Madrid.

Martínez Rivera, F., Díez Díaz, J.,Buitrago, M., Olaya, G., Ladino, A., Duarte, E. and Mafla, E., 2006. Guía para el Deslinde y Amojonamiento, Entidades Territoriales de la República de Colombia. Departamento Nacional de Estadística-DANE, Instituto Geográfico Agustín Codazzi, Colombia, 32. 
Massó, M., Torres, M. and Jiménez, M.M., 2011. La recuperació dels límits municipals històrics, Conveni DGAP-ICC (2005-2011, Revista Catalana de Geografia. Revista digital de geografía, cartografía i ciències de la Terra, 43, vol. XVI. <http://www.rcg.cat/articles.php?id=212> Retrieved 15.01.13.

Moya Rodríguez, M. and García-Rodrigo Martín, A.M., 2002. Catastro, Valoración y Tributación Inmobiliaria Rústica, Editorial Artemedia Comunicación S.L., 454.

Piña García, F., 2009. Doctoral Thesis: Los Límites Administrativos, el Dominio Público y la zonificación del espacio en la Ordenación del Territorio y el Urbanismo, Análisis y evaluación posicional en Cantabria. Departamento de Ingeniería Geográfica y Técnicas de Expresión Gráfica, Universidad de Cantabria.

Pirti, A., Arslan, N. , Deveci, B., Aydin, O. , Erkaya, H. and Hosban, R.G., 2009. Real-Time kinematic GPS for Cadastral Surveying. Survey Review, 41, 339-351.

Pro Ruíz, J., 1992. Estado, geometría y propiedad: Los orígenes del Catastro en España: 1715-1941. Centro de Gestión Catastral y Cooperación Tributaria, Ministerio de Economía y Hacienda, 419.

Pro Ruíz, J., 1999. El Catastro desde el punto de vista histórico. XV Curso de Especialización: Cartografía Catastral Informatizada y Cartografía a grandes escalas.

Reguera Rodríguez, A.T., 2007. La lucha postal por el territorio. Scripta Nova. Revista electrónica de geografía y ciencias sociales, 237, vol. XI. <http://www.ub.edu/geocrit/sn/sn-237.htm> Retrieved 10.07.13.

Tucci, M. and Giordano, A., 2011. Positional accuracy, positional uncertainty, and feature change detection in historical maps: Results of an experiment. Computers, Environment and Urban Systems, $35,452-463$.

Urteaga, L., F. Nadal, F. and Muro, J.I., 2003. Imperialismo y cartografía: La organización de la Comisión Española del Estado Mayor en Marruecos (1881-1882). Scripta Nova. Revista electrónica de geografía y ciencias sociales, 142, vol. VII. <http://www.ub.edu/geocrit/sn/sn-142.htm> Retrieved 10.07.13.

Urteaga, L., 2006. El mapa del norte de Marruecos a escala 1/500.000 y la Conferencia de Algeciras de 1906. Scripta Nova. Revista electrónica de geografía y ciencias sociales, 218, vol. X. <http://www.ub.edu/geocrit/sn/sn-218-58.htm> Retrieved 10.07.13.

Urteaga, L., 2008. Dos décadas de investigación sobre historia de la cartografía catastral en España (1988-2008). Revista CTCatastro, 63, 7-30.

Valcuende del Río, J.M. and Cardia, L.M., 2009. Etnografia das Fronteiras Políticas e Sociais na Amazonia Occidental: Brasil, Perú e Bolivia. Scripta Nova. Revista electrónica de geografía y ciencias sociales, 292, vol. XIII. <http://www.ub.edu/geocrit/sn/sn-292.htm> Retrieved 10.07.13.

Vilalta Nicuesa, A.E., 2005. Expediente de deslinde y acción de deslinde y amojonamiento, Editorial Bosch, Biblioteca Básica de Práctica Procesal, 17, 95. 